\title{
Urea Synthesis after Oral Protein Ingestion in Man
}

\author{
Richard J. Rafoth and Gerald R. Onstad \\ From the Departments of Medicine, Hennepin County Medical Center, and \\ the Minneapolis Veterans Administration Hospital, University of Minnesota \\ Medical School, Minneapolis, Minnesota 55415
}

\begin{abstract}
A B S T R A T In an attempt to assess hepatic functional capacity, hourly urea production, and corresponding serum amino acid concentrations after the ingestion of single protein meals $(60,120$, and $240 \mathrm{~g}$ of protein) were evaluated in 18 normal subjects and in 8 patients with liver disease. In normal subjects, the relationship between urea production and serum amino acid concentration was linear (urea production in milligram urea nitrogen/kilogram lean body mass/hour $=6.3$ times $\mathrm{mg}$ amino acid nitrogen $/ 100 \mathrm{ml}$ minus $20.5 \mathrm{SE}$ of the estimate $6.9, r=0.74, P<0.001)$, and variation of protein intake from 50 to $150 \mathrm{~g}$ /day for 3 days before testing did not change this relationship. The patients demonstrated impairment of urea synthesis proportional to the clinical severity of their liver disease. The potential clinical applications of these findings need to be determined.
\end{abstract}

\section{INTRODUCTION}

In man the liver occupies a central role in protein catabolism with more than $99 \%$ of all urea synthesis taking place in the hepatocyte (1). Although the biochemistry of this process has been well defined on a cellular and subcellular level in both animals and man, limited information on urea production after protein ingestion in humans is available. Urinary urea excretion, which reflects urea synthesis, peaks between 4 and $10 \mathrm{~h}$ after large protein meals (2-5). Daily urea synthesis has been estimated in starved and fed individuals (6), but only one study has directly measured urea production immediately after protein ingestion (7). In that study the protein meals were given over an 8 -h period and urea synthesis measured over 4-h intervals. The authors reported that their subjects reached a maximum rate of urea synthesis which could not be exceeded by increasing the amount of protein ingested, and this rate

Received for publication 27 May 1975 and in revised form 8 July 1975. could be used to separate healthy individuals from patients with cirrhosis.

The aim of the present study was to relate hourly urea production to the corresponding serum amino acid concentrations reached after the ingestion of single protein meals in order to evaluate this relationship as a measure of hepatic function. Both normal and abnormal subjects were tested. In addition, the effect of prior protein intake on this relationship was also investigated.

\section{METHODS}

Subjects and procedures. After obtaining informed consent, 18 healthy individuals ( 11 males and 7 females, ages 22-38 yr) and 8 patients with liver disease, without ascites, were studied. All subjects had normal creatinine and urea clearances. To investigate the effects of prior protein intake on urea production, six normal subjects were studied in a metabolic unit where total protein and caloric intake were controlled for the three days before each testing period. The remainder of the normal subjects recorded their dietary intake for a similar 3-day period and were studied as out-patients. The patients with liver disease were studied as in-patients after at least 3 days of a regular hospital diet.

To initiate and maintain a urine output of at least 120 $\mathrm{ml}$ per hour on the day of the test, the subject would drink $400 \mathrm{ml}$ of water upon awakening and then $200 \mathrm{ml}$ every 30 min for the remainder of the test (usually 8-9 h). $2 \mathrm{~h}$ after awakening a fasting blood specimen was drawn and the test meal eaten. Blood specimens were drawn and urine collected hourly for the remainder of the test period. The blood samples were centrifuged and the serum frozen until analysis. The urine was acidified with hydrochloric acid and samples removed and frozen until analysis.

The test meal consisted of a chocolate flavored liquid mixture of soy protein (Supro 610, Ralston Purina Co., St. Louis, Mo.) and powdered skim milk. The final protein content of $0.17 \mathrm{~g} / \mathrm{ml}$ was $60 \%$ soy protein and $40 \%$ milk protein. Test meals of 1,2 , or $4 \mathrm{~g}$ protein $/ \mathrm{kg}$ lean body mass $(\mathrm{LBM})^{1}$ were given. ${ }^{2}$ The meals of 1 and $2 \mathrm{~g}$

${ }^{1}$ Abbreviations used in this papcr: LBM, lean body mass; TBW, total body water.

${ }^{2}$ The LBM was derived from a nomogram (8): Male [0.195 ht in $\mathrm{cm}+0.297 \mathrm{wt}$ in $\mathrm{kg}-14.013] \div 0.73$; Female $[0.345$ ht in $\mathrm{cm}+0.184$ wt in $\mathrm{kg}-35.270] \div 0.73$. 
protein/kg LBM were ingested over a 15-min period, while the largest meal of $4 \mathrm{~g}$ protein $/ \mathrm{kg} \mathrm{LBM}$ was given in four equal portions over $1 \frac{1}{2} \mathrm{~h}$. All subjects ingested the standard meal of $2 \mathrm{~g}$ protein $/ \mathrm{kg} \mathrm{LBM}$, while four took the higher and lower doses as well. In addition, one subject ingested $20 \mathrm{~g}$ of protein every $20 \mathrm{~min}$ for 8 consecutive $\mathrm{h}$.

Serum amino acid nitrogen was determined using a dinitrofluorobenzene technique (9) with a coefficient of variation in our laboratory of $4 \%$ over the range of $4-9 \mathrm{mg} /$ $100 \mathrm{ml}$. A manifold modification by Dr. C. Bandt (Hennepin County Medical Center) on a Technicon Auto Analyzer (Technicon Instrument Corp., Tarrytown, N. Y.) allowed measurements of serum urea nitrogen within the range of $5.0-35.0 \mathrm{mg} / 100 \mathrm{ml}$ with a coefficient of variation of $1.8 \%$. Urine urea nitrogen was measured using a standard manifold on a Technicon Auto Analyzer (coefficient of variation of $3 \%$ ) (10).

In four subjects urea recovery was investigated using a sterile, pyrogen-free solution of $\left[{ }^{14} \mathrm{C}\right]$ urea (New England Nuclear, Boston, Mass.) with a concentration of $4 \mu \mathrm{Ci} / \mathrm{ml}$. $1 \mathrm{ml}$ was injected into the deltoid muscle and all urine collected in 24-h periods for the subsequent $72 \mathrm{~h}$. A $1 \mathrm{~cm}^{3}$ specimen of urine was diluted with $10 \mathrm{~cm}^{3}$ of Handifluor (Mallinckrodt Chemical Works, St. Louis, Mo.) and counted in duplicate in a Beckman LS 250 liquid scintillation counter (Beckman Instruments, Inc., Fullerton, Calif.).

Because of the possibility that the specific activity of urine after $\left[{ }^{14} \mathrm{C}\right]$ urea injection is not entirely associated with $\left[{ }^{14} \mathrm{C}\right]$ urea, both urine and $\left[{ }^{14} \mathrm{C}\right]$ urea standard solutions

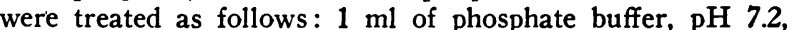
and $1 \mathrm{ml}$ of urease solution, $50 \mathrm{U}$ per $\mathrm{ml}$, (Sigma Chemical Co., St. Louis, Mo.) were added to $2 \mathrm{ml}$ of urine in an uncovered beaker. After $15 \mathrm{~min}$ shaking at $37^{\circ} \mathrm{C}$, dilute $\mathrm{H}_{2} \mathrm{SO}$, was added and shaking continued for another hour. Portions of the remaining solution were again counted in duplicate. Control samples of both urine and standard were treated similarly except phosphate buffer was substituted for the urease solution. Under these conditions, ${ }^{14} \mathrm{CO}_{3}$ should be lost from the urease-treated samples, but $\left[{ }^{14} \mathrm{C}\right]$ urea should remain in the control samples.

Calculations. The basis for calculating urea synthesis is illustrated in Fig. 1. After ingestion, dietary protein is broken down into peptides and amino acids in the alimentary canal and over $90 \%$ is absorbed from the small intestine and transported to the liver as amino acids via the portal vein. Those amino acids which are extracted by the hepatocyte are either deaminated or transaminated and the bulk of the excess nitrogen enters the urea cycle. The remainder is used for protein synthesis throughout the body. The urea produced follows one of three pathways. It may be excreted in urine, equilibrated with the total body water (TBW), or diffused into the intestine where bacterial action, almost exclusively limited to the colon, hydrolyzes it to $\mathrm{CO}_{2}$ and $\mathrm{NH}_{8}$. The $\mathrm{CO}_{2}$ is presumably reabsorbed and expired through the lungs or lost in flatus. The ammonia is reabsorbed and ultimately recycled through the liver.

Urinary urea nitrogen is directly measured. Since urea rapidly diffuses into the total body water with over twothirds of a labeled dose of urea equilibrating within $5 \mathrm{~min}$ of intravenous injection (11), direct measurements of blood urea nitrogen and the use of an estimated figure for TBW allow calculation of the urea which has diffused into the urea space. The third component, the urea lost into the gastrointestinal tract, can also be determined using radioisotopic methods. An intramuscular injection of $\left[{ }^{14} \mathrm{C}\right]-$ urea is presumed to equilibrate rapidly with the urea in the

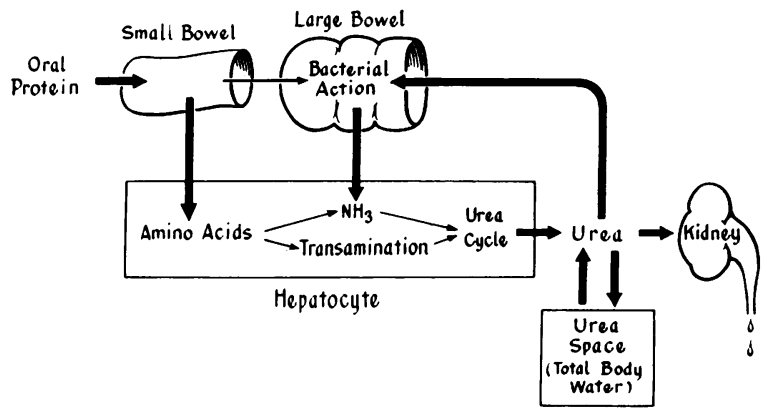

FIGURE 1 Diagrammatic representation of the origin and fate of urea in man. After a protein meal, the urea produced rapidly equilibrates with the total body water and is excreted in urine or is recycled through the gastrointestinal tract.

urea space and can leave this compartment only by renal excretion or by diffusion into the gastrointestinal tract. Over a long period of time, all the isotope is presumed to be completely cleared from the urea space. Using the 72 -h fractional recovery (total recovered/total injected) of the isotope in the urine, the amount of urea lost into the gut over any period of time can be determined. The gastrointestinal loss is the difference between urine area content predicted for $100 \%$ isotope recovery (actual urine urea/ fractional isotope recovery) and the actual urine content.

The LBM, or fat free body weight, correlates closely with the body surface area in normal and obese subjects (8). Because this value was derived to calculate the urea distribution space or TBW ( $0.73 \mathrm{LBM}=\mathrm{TBW})$, it was used in this study to standardize the oral protein meal and urea synthetic rate as well.

\section{RESULTS}

Urea recovery. The number of ${ }^{14} \mathrm{C}$ counts present in urine and standard solution after treatment with urease was less than $5 \%$ (range 1-4\%) of control samples. The total number of counts present in the control samples were almost identical to those of urine diluted directly with Handifluor ${ }^{\mathrm{R}}$.

The urinary recovery of $\left[{ }^{14} \mathrm{C}\right]$ urea from four healthy subjects averaged 95 (range 92-98\%). Since peak urine urea nitrogen excretion after the largest test meal contributed about two-thirds of the total calculated urea synthesis, calculated gastrointestinal urea loss averaged only $3 \%$ of the hourly urea production rate after protein meals. As this loss did not appreciably alter the results of urea production, correction for gastrointestinal loss is not included in subsequent calculations.

Test meals in healthy subjects. Four individuals were tested on three separate occasions with protein meals of 1,2 , and $4 \mathrm{~g}$ protein $/ \mathrm{kg}$ LBM. The responses in Fig. 2 are representative of this group. There appears to be a direct relationship between average hourly serum amino acid concentrations and urea production. Linear regression analysis demonstrated a positive correlation (with 


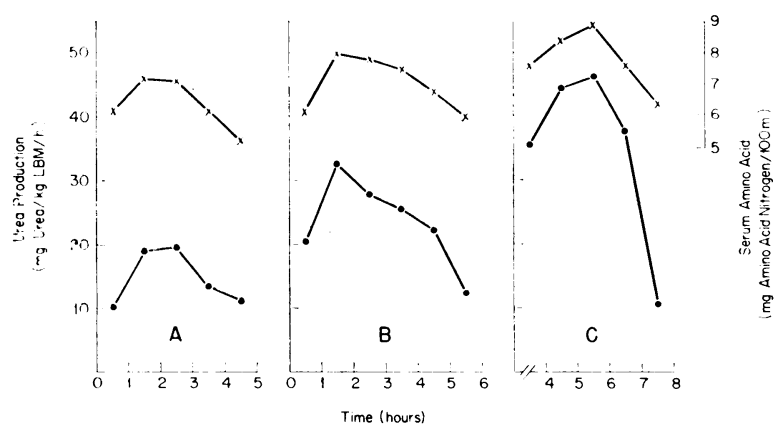

Figure 2 Hourly urea production and hourly average serum amino acid levels after oral protein meals of $1 \mathrm{~g}$ protein $/ \mathrm{kg} \mathrm{LBM} \mathrm{(A),} 2 \mathrm{~g}$ protein $/ \mathrm{kg} \mathrm{LBM} \mathrm{(B),} \mathrm{and} 4 \mathrm{~g}$ protein $/ \mathrm{kg}$ LBM (C). The dots indicate urea production and the $X$ 's, amino acid concentration.

$r$ values ranging from 0.80 to 0.91 ) between the serum amino acid concentration and urea production in each of these four individuals.

Hourly serum amino acid concentration and urea production after protein meals in all 18 normal individuals is plotted in Fig. 3 and shows the same linear relationship between serum amino acid levels and urea production. Using the method of least squares, the equation: urea production ( $\mathrm{mg}$ urea nitrogen/ $\mathrm{kg} \mathrm{LBM}$ ) $=6.3$ times the serum amino acid concentration $(\mathrm{mg}$ amino acid nitrogen $/ 100 \mathrm{ml}$ ) -20.5 ( $\mathrm{SE}$ of estimate $= \pm 6.9, r=0.74, P<0.001)$ was derived.

Effect of diet. To evaluate the effect of diet on urea production, six normal subjects were studied on two separate occasions with the intermediate test meal ( $2 \mathrm{~g}$ pro-

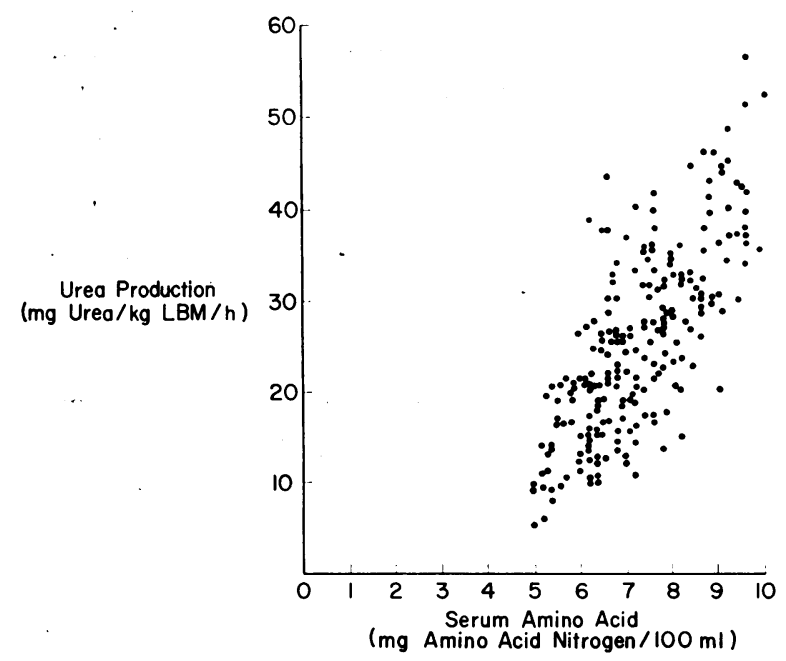

FIGURE 3 . Relationship between hourly urea production and corresponding serum amino acid levels in 18 healthy individuals. The regression equation $\pm \mathrm{SE}$ of the estimate is $Y=6.3 x-20.5 \pm 6.9$. tein $/ \mathrm{kg} \mathrm{LBM}$ ) after a 3-day period of either high (3 g protein $/ \mathrm{kg}$ LBM per day) or low (1 $\mathrm{g}$ protein $/ \mathrm{kg}$ LBM per day) protein intake. Three subjects started with a high-protein diet and three with the low. Statistical analysis showed no difference, either individually or as a group, in peak urea production, hourly serum amino acid concentrations after the test meal, or the slope of the line relating serum amino acid concentration to urea production.

Patients with liver disease. Eight patients with liver disease were studied (Table I). In Fig. 4, the line of best fit for each patient's data is compared with the linear regression line from the group of normals.

The amount of urea produced by these patients appears to be related to the clinical severity of their liver disease. Urea production in the patient with alcoholic fatty liver urea was in the high normal range.

\section{DISCUSSION}

The most striking finding in this study was a linear relationship between serum amino acid concentration and the urea production rate. Within the range of serum amino acid concentration achieved, that concentration, rather than the liver's synthetic ability, was the limiting factor in urea production. These results stand in clear conflict with the conclusions of Rudman et al. (7) who reported a maximum rate of urea synthesis which could not be exceeded by increasing oral protein ingestion. Even though urea synthetic rates one and onehalf times higher than the maximum rate reported by Rudman et al. were achieved in normal subjects in the

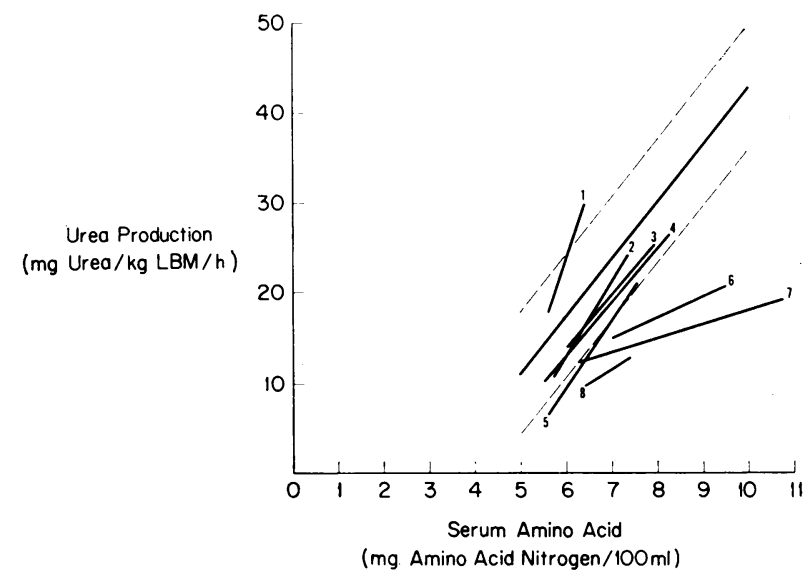

FIGURE 4 The lines of best fit relating hourly urea production and corresponding serum amino acid levels in each of eight patients are compared to the linear regression line $\pm 1 \mathrm{SE}$ of the estimate of the normal group. The lines span the lowest to highest serum amino acid level attained in each patient. The numbers of each line refer to the patients in Table I. 
TABLE I

Clinical Data*

\begin{tabular}{|c|c|c|c|c|c|c|c|c|}
\hline Patient & $\begin{array}{c}\text { Clinical } \\
\text { diagnosis }\end{array}$ & $\begin{array}{c}\text { Liver } \\
\text { - biopsy }\end{array}$ & SGOT & $\begin{array}{c}\text { Alkaline } \\
\text { phosphatase }\end{array}$ & $\begin{array}{c}\text { Bilirubin } \\
\text { (total) }\end{array}$ & $\begin{array}{c}\text { Prothrombin } \\
\text { time }\end{array}$ & Albumin & Globulin \\
\hline 1 & Fatty liver & No & 82 & 101 & 2.1 & 10.5 & 3.8 & 3.5 \\
\hline 2 & Cirrhosis & Yes & 29 & 62 & 1.7 & 12.1 & 4.2 & 2.5 \\
\hline 3 & Viral hepatitis & Yes & 81 & 106 & 2.6 & 12.8 & 3.8 & 4.0 \\
\hline 4 & Chronic aggressive hepatitis & Yes & 200 & 59 & 0.8 & 13.5 & 4.3 & 3.1 \\
\hline 5 & Drug cholestasis & Yes & 52 & 210 & 2.1 & 13.2 & 3.1 & 3.4 \\
\hline 6 & Cirrhosis & Yes & 32 & 76 & 6.1 & 14.2 & 2.1 & 3.0 \\
\hline 7 & Cirrhosis & Yes & 10 & 125 & 7.7 & 15.2 & 1.5 & 6.8 \\
\hline 8 & Cirrhosis & No & 52 & 148 & 2.0 & 17.6 & 3.1 & 4.5 \\
\hline
\end{tabular}

* Normal values for our clinical laboratory are serum glutamic oxalacetic transaminase (SGOT), 4-20 IU ; alkaline phosphatase, 24-96 IU ; bilirubin, $0.2-1.2 \mathrm{mg} / 100 \mathrm{ml}$; prothrombin time, control $12.5 \mathrm{~s}$; albumin, 3.5-5.3 g/100 ml; globulin, 2.4-4.0g/100 ml.

present study, no plateau in production was reached. In their studies, both $4-\mathrm{h}$ callection periods and administration of oral protein in divided doses over 8-h periods would favor a stable rate of urea production. The former by minimizing hourly differences and the latter by causing relatively stable serum amino, acid levels. Furthermore, their largest single meal contained only about $95 \mathrm{~g}$ of protein.

While Fig. 3 shows a good correlation between urea production and serum amino acid levels, extrapolation of the line does not go through the origin. This would suggest that the body conserves amino acid nitrogen below a serum level of $3.5 \mathrm{mg} / 100 \mathrm{ml}$ with essentially no urea production taking place.

In our test, gastrointestinal tolerance of the protein meal was the factor limiting urea production. The $2 \mathrm{~g}$ protein $/ \mathrm{kg} \mathrm{LBM}$ meal was the largest readily tolerated by all individuals. The $4 \mathrm{~g}$ protein $/ \mathrm{kg}$ LBM meal, even though ingested over $1 \frac{1}{2} \mathrm{~h}$, resulted in nausea and bloating for 1-2 $\mathrm{h}$. Even the ingestion of $480 \mathrm{~g}$ of protein over an 8-h period in an attempt to avoid gastrointestinal side effects failed to elevate serum amino acid concentrations above $10 \mathrm{mg} / 100 \mathrm{ml}$.

Since individual amino acids have a variable effect on blood ammonia concentrations (12), a similar effect on urea production might be expected. Thus, the use of a test meal with a different amino acid composition might result in urea production rates either higher or lower than reported here. However, the linear relationship between urea formation and serum amino acid levels presumably would not change.

The gastrointestinal urea loss was only a negligible (3\%) fraction of the total urea synthetic rate in this study. Even if the 72-h recovery of the isotope were in the range of $80 \%$, as reported by others (13), total gastrointestinal loss would still be less than $10 \%$ of the calculated production. It is not clear why our isotope recovery rates were so high. Perhaps the use of a standard $90 \mathrm{~g} /$ day protein diet in young, healthy subjects was responsible.

The level of prior dietary protein intake changes the level of urea cycle enzyme activity and maximum rates of urea production in rat liver homogenates (14-16). However, in our human studies, variation of prior protein intake over a wide range (approximately 50$150 \mathrm{~g} /$ day) failed to change the amino acid-urea production relationship, the fasting serum amino acid level, or the range of hourly serum amino acid concentrations after the test meal.

The relationship of serum amino acid concentration and urea production is in many ways akin to a clearance phenomenon. Using this concept, some patients with clinically mild liver disease show clearance rates within the normal range, while those with more severe disease show a definite impairment of this function, either from shunting of blood or from a decrease in effective hepatocyte mass. Unfortunately, peripheral blood amino acid levels only indirectly reflect portal venous concentrations and so calculation of an absolute clearance rate based on peripheral values is meaningless.

The liver appears to have a remarkable capacity to degrade amino acids to urea. In fact the reserve capacity for this function is so great that only one patient has been reported with such severe liver disease that no urea formation was detectable (17). The human organism appears to have an extremely effective method to degrade excess dietary protein, and this metabolic pathway, located entirely in the hepatocyte, is so efficient that it is one of the last to cease functioning before the death of the cell.

Manipulation of the serum amino acid-urea production relationship, either on a hormonal or drug basis, could have several clinical applications. If this relationship could be influenced in favor of greater urea production, the same methods might be applied to patients with hyperammonemia and hepatic encephalopathy. 
A shift in the opposite direction, toward lower urea production, might be adapted to allow conservation of amino acids for other vital synthetic functions and decrease the minimum daily protein requirement or aid in the therapy of patients with renal failure.

\section{ACKNOWLEDGMENTS}

The authors are indebted to Dr. L. Zieve, Minneapolis Veterans Administration Hospital, for his help, support, and encouragement; Dr. M. Walser, Johns Hopkins School of Medicine, for the Urease Method; and Dr. M. Levitt, University of Minnesota Hospitals, for his critical comments. The excellent technical assistance of Ms. S. Racek is gratefully acknowledged.

The research was supported in part by the John $B$. Hawley, Jr. Medical Research Fund of the Minneapolis Medical Research Foundation, Inc., and the Minneapolis Veterans Administration Hospital Traineeship in Gastroenterology.

\section{REFERENCES}

1. Levin, B. 1971. Hereditary metabolic disorders of the urea cycle. Adv. Clin. Chem. 14: 65-143.

2. Aub, J. C., and E. F. Du Bois. 1917. The basal metabolism of dwarfs and legless men with observations on the specific dynamic action of protein. Arch. Intern. Med. 19: 840-864.

3. Aub, J. C., and J. H. Means. 1921. The basal metabolism and the specific dynamic action of protein in liver disease. Arch. Intern. Med. 28: 173-191.

4. Greenblatt, I. J., and T. D. Cohn. 1946. Azotemia in gastro-intestinal bleeding. The ingestion of shed blood in humans. Am. J. Med. Sci. 211: 565-570.

5. Cohn, T. D., M. Lane, S. Zuckerman, N. Messinger, and A. Griffith. 1956. Induced azotemia in humans following massive protein and blood ingestion and the mechanism of azotemia in gastrointestinal hemorrhage. Am. J. Med. Sci. 231: 394-401.
6. Picou, D., and M. Phillips. 1972. Urea metabolism in malnourished and recovered children receiving a high or low protein diet. Am. J. Clin. Nutr. 25: 1261-1266.

7. Rudman, D., T. J. DiFulco, J. T. Galambos, R. B. Smith, III, A. A. Salam, and W. D. Warren. 1973. Maximal rates of excretion and snythesis of urea in normal and cirrhotic subjects. J. Clin. Invest. 52: 22412249.

8. Hume, R., and E. Weyers. 1971. Relationship between total body water and surface area in normal and obese subjects. J. Clin. Pathol. (Lond.). 24: 234-238.

9. Goodwin, J. F. 1970. Spectrophotometric quantitation of plasma and urinary amino nitrogen with fluorodinitrobenzene. Stand. Methods Clin. Chem. 6: 89-98.

10. Marsh, W. H., B. Fingerhut, and H. Miller. 1965. Automated and manual direct methods for the determination of blood urea. Clin. Chem. 11: 624-627.

11. San Pietro, A., and D. Rittenberg. 1953. A study of the rate of protein synthesis in humans. Measurements of the urea pool and urea space. J. Biol. Chem. 201: 445-455.

12. Rudman, D., J. T. Galambos, R. B. Smith, III, A. A. Salam, and W. D. Warren. 1973. Comparison of the effect of various amino acids upon the blood ammonia concentration of patients with liver disease. Am. J. Clin. Nutr. 26: 916-925.

13. Walser, M., and L. J. Bodenlos. 1959. Urea metabolism in man. J. Clin. Invest. 38: 1617-1626.

14. Schimke, R. T. 1962. Adaptive characteristics of urea cycle enzymes in the rat. J. Biol. Chem. 237: 459-468.

15. Schimke, R. T. 1963. Studies on factors affecting the levels of urea cycle enzymes in rat liver. J. Biol. Chem. 238: 1012-1018.

16. Ashida, K., and A. E. Harper. 1961. Metabolic adaptations in higher animals. VI. Liver arginase activity during adaptation to high protein. Proc. Soc. Exp. Biol. Med. 107 : 151-157.

17. Rabinowitch, I. M. 1929. Biochemical findings in a rare case of acute yellow atrophy of the liver. J. Biol. Chem. 83: 333-335. 